\title{
PENGARUH LEMBAR KERJA SISWA (LKS) BERBASIS PENDEKATAN INDUKTIF TERHADAP KEMAMPUAN BERPIKIR KRITIS SISWA PADA MATERI KELARUTAN DAN HASIL KALI KELARUTAN DI SMA NEGERI 12 BANJARMASIN
}

\author{
The Effect of Student Worksheet Based On Inductive Approach To Student's \\ Critical Thinking Skills On Solubility and Solubility Result Material In SMA \\ Negeri 12 Banjarmasin
}

\author{
Rifda Salsa Khairiyah , Raden Roro Ariessanty Alicia Kusuma Wardhani, Herlina \\ Apriani
}

Program Studi Pendidikan Kimia Fakultas Keguruan dan Ilmu Pendidikan Universitas Islam Kalimantan (Uniska) Muhammad Arsyad Al Banjari, Banjarmasin *e-mail: rifdasalsakhairiyah@gmail.com

\begin{abstract}
Abstrak. Penelitian ini bertujuan untuk mengetahui pengaruh lembar kerja siswa (LKS) berbasis pendekatan induktif terhadap kemampuan berpikir kritis siswa pada materi kelarutan dan hasil kali kelarutan. Penelitian ini dilaksanakan di SMA Negeri 12 Banjarmasin dengan menggunakan metode eksperimen yang melibatkan dua kelompok belajar yaitu kelas eksperimen dan kelas kontrol dengan desain penelitian posttest only control group design. Sampel dalam penelitian ini sebanyak 48 sampel yang terdiri dari kelas eksperimen berjumlah 23 siswa dan kelas kontrol berjumlah 25 siswa. Instrumen yang digunakan untuk mengumpulkan data dalam penelitian ini adalah angket kemampuan berpikir kritis. Hasil penelitian menunjukkan bahwa pembelajaran yang menggunakan lembar kerja siswa berbasis pendekatan induktif dapat meningkatkan kemampuan berpikir kritis siswa dalam belajar pada materi kelarutan dan hasil kali kelarutan di SMA Negeri 12 Banjarmasin. Hal ini dapat dilihat pada hasil uji hipotesis yang menggunakan uji mann-whitney. Hasil yang didapatkan adalah nilai sig sebesar 0,036, yang menyatakan $\mathrm{H}_{0}$ ditolak dan $\mathrm{H}_{1}$ diterima, hal ini dikarenakan nilai sig $<0,05$.
\end{abstract}

Kata Kunci: Kelarutan dan hasil kali kelarutan, kemampuan berpikir kritis $L K S$, pendekatan induktif

\begin{abstract}
This study aims to determine students' critical thinking skills by using student worksheet based on inductive approach to student's critical thinking skills on solubility and solubility results material. This research was conducted at SMA Negeri 12 Banjarmasin by using an experimental method involving the two study groups namely experimental class and control class with the research design used is the posstest only control group design. The sample in this study were 48 samples consisting of an experimental class 23 students and a control class 25 students. Instrument used to collect data were questionnaires of thinking skill. The result showed that learning with worksheet based on an inductive approach can improve students' critical thinking skills in learning the material solubilty and solubility results at SMA Negeri 12 Banjarmasin. This can be seen in the results of hypothesis testing using the Mann Whitney test. The results obtained are sig value
\end{abstract}


of 0,036, which states that $H_{0}$ is rejected and $H_{1}$ is accepted, this is because sig < 0,05 .

Keywords:, Critical thinking skills, inductive approach, , solubility and solubility result, worksheet

\section{PENDAHULUAN}

Pendidikan adalah tonggak kemajuan bangsa dimana faktor pendidikan sangat berpengaruh bagi pembangunan bangsa. Peningkatan kualitas pendidikan nasional ditandai dengan penyempurnaan yang terjadi pada setiap aspek pendidikan. Proses pendidikan diharapkan agar dapat menyiapkan serta menghasilkan sumber daya manusia yang berkualitas agar dapat memproses informasi dengan baik dan benar.

Salah satu upaya yang dapat dilakukan dalam bidang pendidikan untuk mencetak SDM yang berkualitas yaitu membentuk budaya berpikir kritis pada siswa dalam proses belajar. Menurut Ennis (2011), berpikir kritis merupakan kemampuan berpikir yang reflektif, dimana fokus kemampuan tersebut adalah pada pola pengambilan keputusan mengenai apa yang harus diyakini dan dilakukan. Menganalisis, mensintesis dan menyimpulkan informasi yang didapat melalui kemampuan berpikir kritis adalah hal yang harus dikuasai siswa agar ia mampu melihat perbedaan informasi yang baik dan buruk, selain itu juga mampu mengambil keputusan terhadap informasi yang didapat melalui berpikir kritis. Selain itu menurut Redhana dan Liliasari dalam Zumisa (2013), kemampuan berpikir kritis siswa perlu dilatih untuk menyiapkan siswa menjadi seorang pemikir kritis dan independen, serta mampu memecahkan masalah, sehingga mereka dapat menghindari segala bentuk indoktrinasi, penipuan, pencucian otak, serta mengatasi setiap masalah yang dihadapi, dan membuat keputusan dengan tepat dan bertanggung jawab dalam kehidupan.

Faktor-faktor yang mempengaruhi kelarutan merupakan salah satu submateri dalam ilmu kimia yang diberikan di kelas XI SMA. Pokok pembahasan dalam materi faktor-faktor yang mempengaruhi kelarutan ini sebenarnya sangat menarik dan akrab dalam kehidupan sehari-hari, sehingga proses pembelajaran dapat lebih realistis. Namun, sistem pembelajaran yang hanya bersifat teoritis dan berpusat kepada guru membuat sebagian besar siswa belum dapat menangkap makna dari apa yang mereka peroleh dari pembelajaran untuk dapat diterapkan dalam kehidupan sehari-hari sehingga siswa merasa kurang bergairah atau bosan dan kesulitan dalam mengikuti pembelajaran kimia karena dianggap tidak ada manfaat praktis dalam kehidupan sehari-hari. Kondisi seperti ini mengharuskan guru memiliki kemampuan merancang pembelajaran untuk membekali pengetahuan secara teoritis maupun praktek kepada siswa dan menciptakan kondisi belajar yang efektif sehingga lebih mudah bagi siswa untuk memahami, memaknai, dan berpikir kritis serta menghubungkan materi pelajaran yang mereka pelajari dengan kehidupan nyata. Oleh karena itu, maka pembelajaran dengan pendekatan induktif dirasa cocok untuk mengatasi masalah tersebut karena pembelajaran tersebut dapat melatih siswa membentuk dan menggeneralisasikan konsep. Pembelajaran ini juga mengarahkan perhatian siswa agar fokus tidak hanya pada logika, tetapi juga pada bahasa dan sifat pengetahuan (Joyce, 2009)

Untuk lebih memaksimalkan kemampuan berpikir kritis siswa maka diperlukan media yang tepat, yaitu lembar kerja siswa (LKS). Lembar kerja siswa (LKS) yang 
berbasis pendekatan induktif diharapkan dapat membuat siswa terlibat aktif dengan materi yang dibahas dan memberikan pengalaman belajar siswa saat pengerjaan latihan soal. Siswa mampu mengatasi masalah dalam pembelajaran sehingga mampu mengkontruksikan sendiri pengetahuannya dan menjawab kebutuhan kurikulum yang akan datang. Maka dari itu, dilakukan sebuah penelitian menggunakan LKS berbasis pendekatan induktif untuk mengetahui seberapa besar pengaruhnya terhadap kemampuan berpikir kritis siswa.

\section{METODE PENELITIAN}

Penelitian ini menggunakan jenis penelitian quasy experiment dengan desain penelitian posttest-only control group design. Selama bulan april 2018 sampai dengan penelitian selesai, pelaksanaan penelitian ini bertempat di SMA Negeri 12 Banjarmasin. Sampel yang digunakan terdiri dari dua buah, yaitu kelas XI IPA 2 dan XI IPA 3 dari populasi seluruh siswa kelas XI IPA di SMA Negeri 12 Banjarmasin. Teknik pengambilan sampel yang digunakan adalah teknik cluster sampling karena sampel yang digunakan dalam penelitian terdiri dari kelompok, bukan individu.

Instrumen yang digunakan untuk mengukur kemampuan berpikir kritis dalam penelitian ini adalah angket kemampuan berpikir kritis yang terdiri dari 7 aspek dan 21 pernyataan. Untuk setiap aspek dan pernyataan memiliki poin berskala 0-2. Teknik analisis data yang digunakan adalah uji prasyarat yaitu uji normalitas dan uji homogenitas dimana kedua uji ini bertujuan untuk mengetahui ada tidaknya perbedaan pada hasil penelitian antara kedua sampel, yaitu kelas eksperimen dan kelas kontrol.

Setelah diadakan uji prasyarat tersebut, maka dilakukan uji statistik nonparametrik yaitu uji mann whitney, uji ini menggunakan program spss tipe 16.0 dengan kriteria sebagai berikut : Jika sig $>0,05 \mathrm{H}_{0}$ diterima, $\mathrm{H}_{1}$ ditolak, jika sig $<0,05 \mathrm{H}_{0}$ ditolak, $\mathrm{H}_{1}$ diterima (Sarwono, 2012).

\section{HASIL DAN PEMBAHASAN}

Hasil analisis data jawaban siswa dalam angket kemampuan berpikir kritis menunjukkan bahwa terdapat pengaruh yang signifikan terhadap kemampuan berpikir kritis siswa pada penggunaan LKS berbasis pendekatan induktif. Hasil analisis data dapat dilihat pada tabel 3 .

Tabel 1 Hasil uji Mann-Whitney

\begin{tabular}{c|r|c|c}
\hline Mann-Whitney $U$ & $\mathrm{Z}$ & Sig. & Keterangan \\
\hline 186.50 & - & & \\
0 & 2.096 & 0.036 & Terdapat pengaruh \\
\hline
\end{tabular}

Hasil analisis data menunjukkan bahwa pembelajaran dengan LKS berbasis pendekatan induktif yang digunakan oleh siswa kelas eksperimen dapat meningkatkan kemampuan berpikir kritis siswa dibandingkan dengan siswa kelas kontrol yang mendapatkan pembelajaran konvensional. Sesuai dengan hasil penelitian Tarmiz, dkk (2017) yang membuktikan bahwa lembar kerja siswa dapat meningkatkan keterampilan berpikir siswa dalam belajar dengan ditunjukkannya hasil uji mann-whitney terhadap kedua kelas tersebut.

Lembar kerja siswa berbasis pendekatan induktif ini menyajikan data atau konsep dan contoh-contoh konsep, prinsip atau aturan yang memungkinkan siswa 
memperkirakan (membuat hipotesis) sifat umum yang terkandung dalam contoh yang disajikan tersebut. Bukti berupa contoh tambahan juga disajikan untuk menunjang atau menyangkal perkiraan tersebut, kemudian pertanyaan mengenai sifat umum yang telah terbukti disusun setelahnya. Hal ini dapat merangsang siswa berpikir kritis untuk menemukan ide pokok dan berusaha menyelesaikan tugas yang diberikan. Belajar dengan LKS dapat menjadikan siswa lebih berpengalaman dalam belajar (Kisiel, 2003; Mortensen dan Smart, 2007). LKS yang berbasis pendekatan induktif ini, dapat melatih siswa berpikir kritis. Hal ini sesuai studi Redhana dan Liliasari (2008), dimana LKS sangat efektif dalam meningkatkan kemampuan berpikir kritis siswa, bahkan pada siswa yang memiliki kemampuan yang rendah.

Penggunaan LKS berbasis pendekatan induktif adalah salah satu faktor yang membuat pembelajaran lebih efektif. Pembelajaran dengan menggunakan LKS berbasis pendekatan induktif menjadikan siswa lebih aktif dalam proses pembelajaran, sehingga siswa terampil dalam berpikir. Sebaliknya jika dibandingkan dengan kelas kontrol yang menggunakan pembelajaran konvensional dimana proses pembelajaran hanya berpusat pada guru. Hal ini sesuai dengan hasil penelitian Rahayu (2015) dimana ia menyatakan bahwa lembar kerja siswa berpengaruh dalam meningkatkan kemampuan berpikir kritis siswa. Hasil yang diperoleh adalah peningkatan kemampuan berpikir kritis siswa yang menggunakan LKS berbasis pendekatan induktif lebih baik dibandingkan dengan cara konvensional, selain itu faktor pendekatan pembelajaran memiliki peran yang lebih besar dalam pencapaian kemampuan berpikir kritis.

Peningkatan kemampuan berpikir kritis siswa untuk kategori tinggi paling besar adalah pada indikator "menggunakan prosedur". Hal ini dikarenakan siswa sudah terlatih dalam belajar dengan LKS berbasis pendekatan induktif yang menuntut siswa mampu berargumen, melakukan percobaan untuk memecahkan permasalahan dan mencari solusi untuk permasalahan tersebut (Fatma dan Ummuhan, 2012). Selain itu, menurut Joyce (2009), pendekatan induktif mengarahkan perhatian siswa untuk fokus tidak hanya pada logika, tetapi juga pada bahasa dan arti kata-kata, serta sifat pengetahuan. LKS berbasis pendekatan induktif berfokus pada penyajian suatu permasalahan (nyata atau simulasi) kepada siswa, kemudian siswa menemukan solusi melalui penelitian dan investigasi sesuai dengan teori, konsep, prinsip yang dipelajari dari berbagai bidang ilmu.

\section{SIMPULAN}

Berdasarkan hasil penelitian dan pembahasan, dapat disimpulkan bahwa pembelajaran dengan menggunakan LKS berbasis pendekatan induktif dapat meningkatkan kemampuan berpikir kritis siswa dalam mempelajari materi kelarutan dan hasil kali kelarutan di SMA Negeri 12 Banjarmasin, hal ini dapat dilihat dari uji mannwhitney yang memperoleh nilai signifikansi sebesar 0,036 $<0,05$.

\section{DAFTAR RUJUKAN}

Ennis R.H. (2011). The Nature of Critical thinking: An Outline of Critical Thinking Dispositions and Abilities. Universitas of Illinois.

Fatma, S.O., \& Ummuhan, O. (2012). An Application about Pre-Service Teachers' Development and Use of Worksheets and an Evaluation of their Opinions 
Dalton : Jurnal Pendidikan Kimia dan Ilmu Kimia, Volume 2 Nomor 1, Mei 2019

about the Application. Journal Educational Sciences: Theory and Practice, 12(1):263-270.

Joyce, B. 2009. Model of Teaching, Model-model Pembelajaran. Yogyakarta: Pustaka Pelajar.

Kisiel, J. F. (2003). Teachers, Museums and Worksheets: a Closer Look at a Learning Experience. Journal of Science Teacher Education, 14(1): 3-21.

Rahayu, A. T. (201)5. Pengaruh Pembelajaran Kontekstual Terhadap Keterampilan Berpikir Kritis Siswa Submateri Faktor-Faktor Yang Mempengaruhi Laju Reaksi Melalui Praktikum. Skripsi. Banjarmasin: Universitas Islam Kalimantan Muhammad Arsyad Al-Banjari

Redhana, I dan Liliasari. (2008). Program Pembelajaran Keterampilan Berpikir Kritis pada Topik Laju Reaksi untuk Siswa SMA. Forum Kependidikan, 27(2):103112.

Sarwono, J. (2012). IBM SPSS "Advancees Statistic". Prosedur-prosedur Generalisasi dan Perluasan General Linear Model (GLM). Yogyakarta: ANDI

Tarmizi, dkk 2017. Penggunaan LKS Berbasis PBL Terhadap Keterampilan Berpikir Kritis Siswa Pada Materi Cahaya di Smpn 1 Kembang Tanjong. Jurnal Pendidikan Sains Indonesia.

Prayoga Z. N. (2013). Kemampuan Berpikir Kritis Siswa Pada Pembelajaran Pada Materi Pengelolaan Lingkungan Dengan Pendekatan Keterampilan Proses Sains. Skripsi 42-49. Jurusan Biologi Fakultas Matematika dan Ilmu Pengetahuan Alam Universitas Negeri Semarang. Semarang. 